INTERNATIONAL JOURNAL OF RESEARCHES IN BIOSCIENCES, AGRICULTURE AND TECHNOLOGY (C) VISHWASHANTI MULTIPURPOSE SOCIETY (Global Peace Multipurpose Society) R. No. MH-659/13(N) www.vmsindia.org

\title{
EFFECT OF DIFFERENT SOURCES OF NUTRIENTS ON GROWTH, YIELD AND QUALITY OF NAGPUR MANDARIN
}

\author{
V. P. Babhulkar, P. R. Kadu and D. J. Jiwtode \\ College Of Agriculture, Nagpur- (M.S.) India \\ Deptt of Agril. Chemistry and Soil Science \\ Dr. Panjabrao Deshmukh Krishi Vidyapeeth, \\ Akola, Maharashtra- 444104
}

\section{INTRODUCTION}

The organic manure plays a very important role in maintaining soil productivity. Oil cakes increased organic carbon, phosphorous content in soil. Edible oil cakes release more inorganic nitrogen from soil than non-edible cakes. Non-edible oil cakes liberated available phosphorus from soil in greater proportions than edible oil cakes. Karanj and neem cakes being non-edible are used exclusively as manure in fruit crops. Among these, neem cake is very popular with our farmers cultivating fruit crops. It is non-edible concentrated organic manure, easily available and contained high amount of nitrogen and organic carbon. They also retard nematode population in soil, if present in hazardous amount. Gandhi (1) has also recommended the utility of oil cakes in fertilizer mixtures. Citrus is a nutrient sensitive and responsive plant and it

\section{RESULTS AND DISCUSSION}

Table 2 revealed that, tree volume of Nagpur mandarin was not significantly influenced by different treatments of manuring. Numerically the maximum tree volume was recorded in treatment $\mathrm{Tl}$ (46.69) followed by $\mathrm{T} 7$ (46.32). But in respect of fruit yield during ambia and mrig bahar significantly higher fruit yield (395.6 and 356.5, respectively) was obtained from the trees with applied with T4 (50 $\mathrm{Kg}$ FYM $+10 \mathrm{Kg}$ " Neem cake). These results confirm the findings of Rokba et al (3). The minimum fruit yield (298.6 fruits) was obtained in the treatment T7 where the fertilizer was applied of FYM + PSB of ambia bahar where as in Mrig bahar it was in treatment T5 and T7 where the FYM + PSB applied.

\section{Physico-chemical characteristics of fruits:}

Fruit weight, fruit size and juice percent were significantly influenced by various treatments of organic and inorganic fertilizers in ambia bahar (Table-3). The maximum fruit was found in treatment $\mathrm{T} 4$ required adequate nutrition for proper growth and development (Ghosh, 2).

\section{MATERIAL AND METHODS}

The present investigation was carried out on twelve years old Nagpur mandarin plants of uniform growth and vigor at Regional Fruit Research Station, Katol, Distt. Nagpur. The general characteristics of experimental soil and chemical properties of neem cake, FYM and sunhemp have been mentioned along with treatment details (Table 1). The finely ground well powdered neem cake was used. The PSB was applied $20 \mathrm{~g} /$ tree. All the fertilizers and organic manures were applied in the month of June. The treatments were applied in randomizes block design with three replications having two plants under each treatment. Growth of plant, number of fruits per plant were counted. Physico-chemical characters of fruits were measured.

where $50 \mathrm{Kg}$ FYM and $10 \mathrm{Kg}$ neem cake applied. The fruit size (height and diameter) was more in application of organic fertilizer i.e. $50 \mathrm{Kg}$ FYM and $10 \mathrm{Kg}$ neem cake. This may be due to enhanced merelization of organic nitrogen. The maximum juice percent was recorded in treatments $\mathrm{T} 4$ followed by T3. The TSS and acidity could not influenced by various treatments in ambia bahar, but maximum TSS and low acidity was recorded where organic fertilizer applied i.e. T4 .

During mrig bahar the fruit weight and fruit size could not be influenced by various treatments combination (table 4). The maximum fruit weight and more fruit size was observed in organic fertilizer application i.e. $50 \mathrm{Kg}$ FYM $+10 \mathrm{Kg}$ neem cake applied. The juice percent also more in this treatment. The TSS and acidity was significantly influenced by various treatments. The maximum TSS and minimum acidity was recorded in treatment $\mathrm{T} 4$ where $50 \mathrm{Kg} \mathrm{FYM}+10 \mathrm{Kg}$ neem cake applied. However, the desirable parameters 
were exhibited by applying the organic fertilizer in the form of $50 \mathrm{Kg} F Y M+10 \mathrm{Kg}$ neem cake. The present investigation is in

Table 1: General characteristics of experimental soil

\begin{tabular}{|c|l|l|l|}
\hline $\begin{array}{r}\text { Sr. } \\
\text { No. }\end{array}$ & Soil status & Initial & Final \\
\hline 1. & Bulk density g/ $\mathrm{cm}^{3}$ & 1.56 & 1.54 \\
\hline 2. & pH & 7.3 & 7.1 \\
\hline 3. & EC dsm"1 & 0.35 & 0.32 \\
\hline 4. & Organic carbon (\%) & 0.52 & 0.54 \\
\hline 5. & Available $\mathrm{P}_{2} \mathrm{O}$ kg ha"1 & 46 & 49 \\
\hline 6. & Available $\mathrm{K}_{2} \mathrm{O}$ kg ha'1 & 430 & 439 \\
\hline
\end{tabular}

the line of findings of Rokba et.al. (3) and Tiwarie/a/. (4).

Chemical analysis of FYM, neem cake and sunhemp

\begin{tabular}{|c|c|c|c|c|}
\hline Sr.No. & & $\mathrm{N}$ & $\mathrm{P}$ & $\mathrm{K}$ \\
\hline 1. & FYM & 0.84 & 0.59 & 1.35 \\
\hline 2. & Neem cake & 4.48 & 0.85 & 1.85 \\
\hline 3. & Sunhemp & 2.24 & 0.87 & 0.85 \\
\hline
\end{tabular}

Treatment details

\begin{tabular}{|c|c|}
\hline $\mathrm{Tl}$ & $1200 \mathrm{~g} \mathrm{~N}+400 \mathrm{~g} \mathrm{P}_{2} \mathrm{O}_{5}+400 \mathrm{~g} \mathrm{~K}_{2} \mathrm{O}+25 \mathrm{Kg} F Y M$ \\
\hline $\mathrm{T} 2$ & 900 g N + 300 g P $_{2} \mathrm{O}_{5}+300 \mathrm{~g} \mathrm{~K}_{2} \mathrm{O}+50 \mathrm{Kg} \mathrm{FYM}$ \\
\hline T3 & SO Kg FYM \\
\hline T4 & $50 \mathrm{Kg} F Y M+10 \mathrm{Kg}$ neem cake \\
\hline T5 & $50 \mathrm{Kg}$ FYM+ Sowing of sunhemp around the basin (rainy and summer season) \\
\hline T6 & 900 g N+300g $\mathrm{P}_{2} \mathrm{O}_{5}+300 \mathrm{~g} \mathrm{~K}_{2} \mathrm{O}+50 \mathrm{Kg} \mathrm{FYM}+\mathrm{PSB}(20 \mathrm{~g} /$ tree $)$ \\
\hline T7 & $50 \mathrm{Kg}$ FYM + PSB (20g/tree) \\
\hline
\end{tabular}

Table 2: Tree volume and yield of Nagpur mandarin as influenced by different treatments of nutrients (Pooled results of 1999-2000 to 2005-2006)

\begin{tabular}{|c|c|c|c|}
\hline Treatments & Tree volume (cu.m.) & Fruit yield (No) in ambia bahar & Fruit yield (No) in mrig bahar \\
\hline Tl & 46.69 & 372.4 & 324.7 \\
\hline T2 & 45.57 & 344.8 & 306.6 \\
\hline T3 & 45.85 & 311.2 & 304.5 \\
\hline T4 & 44.73 & 395.6 & 356.5 \\
\hline T5 & 45.08 & 358.6 & 265.0 \\
\hline T6 & 44.18 & 324.0 & 312.0 \\
\hline T7 & 46.32 & 298.6 & 269.2 \\
\hline SE $(\mathrm{m}) \pm$ & 0.89 & 18.7 & 15.88 \\
\hline CD at $5 \%$ & N.S. & 54.6 & 47.18 \\
\hline
\end{tabular}

Table 3: Physico-chemical properties of Ambia bahar fruit of Nagpur mandarin as influence by different treatments of nutrients (Pooled results of 1999-2000 to 2005-2006).

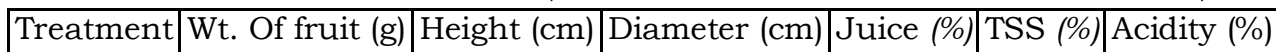

\begin{tabular}{|c|l|c|c|c|c|c|}
\hline T1 & 147.0 & 5.16 & 5.57 & 43.28 & 8.40 & 0.72 \\
\hline T2 & 145.3 & 5.21 & 5.70 & 43.96 & 8.38 & 0.72 \\
\hline T3 & 144.7 & 5.59 & 5.47 & 44.38 & 8.26 & 0.71 \\
\hline T4 & 159.8 & 5.57 & 5.71 & 45.68 & 8.58 & 0.54 \\
\hline T5 & 140.2 & 5.18 & 5.40 & 43.32 & 8.34 & 0.69 \\
\hline T6 & 140.8 & 4.85 & 5.29 & 42.44 & 8.40 & 0.60 \\
\hline T7 & 139.3 & 5.00 & 5.21 & 42.64 & 8.46 & 0.60 \\
\hline SE $(\mathrm{m})+$ & 2.9 & 0.09 & 0.09 & 0.61 & 0.085 & 0.014 \\
\hline CD at 5\% & 8.56 & 0.26 & 2.36 & 1.85 & N.S. & N.S. \\
\hline
\end{tabular}


Table 4: Physico-chemical properties of Mrig bahar fruit of Nagpur mandarin as influence by different treatments of nutrients (Pooled results of 1999-2000 to 2005-2006).

\begin{tabular}{|c|c|c|c|c|c|c|}
\hline Treatments & Weight of fruit $(\mathrm{g})$ & Height $(\mathrm{cm})$ & Diameter $(\mathrm{cm})$ & Juice (\%) & TSS (\%) & Acidity (\%) \\
\hline T1 & 135.82 & 4.99 & 5.47 & 44.63 & 9.50 & 0.73 \\
\hline T2 & 121.22 & 5.05 & 5.50 & 46.56 & 9.47 & 0.75 \\
\hline T3 & 145.02 & 5.19 & 5.45 & 46.23 & 9.57 & 0.77 \\
\hline T4 & 151.95 & 5.26 & 5.90 & 47.26 & 9.60 & 0.57 \\
\hline T5 & 145.87 & 5.15 & 5.78 & 45.79 & 9.35 & 0.77 \\
\hline T6 & 122.30 & 5.11 & 5.62 & 46.15 & 9.42 & 0.72 \\
\hline T7 & 147.88 & 5.11 & 5.71 & 45.87 & 9.30 & 0.60 \\
\hline SE $(\mathrm{m}) \pm$ & 9.91 & 0.07 & 0.12 & 0.54 & 0.06 & 0.014 \\
\hline CD at 5\% & N.S. & N.S. & N.S. & 1.59 & 0.187 & 0.041 \\
\hline
\end{tabular}

\section{SUMMARY}

A field experiment was conducted during $1999-2000$ to $2005-2006$ to study the effect of organic and inorganic nutrients with biofertilizers on Nagpur mandarin. Results indicated that, tree applied with $50 \mathrm{Kg}$ FYM +10 $\mathrm{Kg}$ neem cake influence the fruit yield during ambia and mrig bahar. Desirable parameters of physico-chemical characteristics' of fruits were also exhibited due to the application of organic manures, inorganic and bio-fertilizers.

\section{References:}

1. Gandhi, S.R. (1956). Oranges, lemons and limes in India. P.M. Bull. Indian Coun. Agric. Res. 15:28-29.
2. Ghosh, S.N. (1990). National requirement of orange (Citrus sinensis osbeck) cv . Mosambi. Haryana. J. Hort. Sci. 19 (1-2): 39-44.

3. Rokba, A. M, El. L.T. Mahmoundi and El.E.Menshawi. (1975). Effect of organic and inorganic fertilizer on annual orange trees. Agril. Res. Review. 53(3):7-14. Horticulture Res. Station, sabhia,Alexandra UAR.

4. Tiwari, U.S., C.V. Pujari, D.D. Jagtap and S.B.Rajadhav. (1999). Effect of organic and inorganic fertilizers on yield and quality of sweet orange (Citrus sinensis). Proc. Int. Soc. Citriculture: 389-396. 